\title{
Perspectives
}

\section{Anecdotal, Historical and Critical Commentaries on Genetics}

\author{
Edited by James F. Crow and William F. Dove
}

\section{Theodosius Dobzhansky's Role in the Emergence and Institutionalization of Genetics in Mexico}

\author{
Ana Barahona*,1 and Francisco J. Ayala ${ }^{\dagger}$ \\ *Departamento de Biología Evolutiva, Facultad de Ciencias, UNAM, Coyoacán 04510, México and ${ }^{\dagger}$ Department of \\ Ecology and Evolutionary Biology, University of California, Irvine, California 92697
}

$\mathrm{T}$ HE science of genetics was introduced in Mexico at the beginning of the twentieth century by the agronomist Edmundo Taboada, who studied in the United States at Cornell University under the direction of Rollins Emerson. For earlier Perspectives on Emerson, see Nelson (1993) and Kass et al. (2005). Taboada occupied several positions in Mexican agricultural institutions, held a professorship in the Escuela Nacional de Agricultura (National School of Agriculture), and in 1939 published the first Mexican textbook on genetics. In the 1940s and thereafter, genetics was impelled in Mexico by exiled Spanish scientists, who taught and worked primarily at the Escuela Nacional de Ciencias Biológicas del IPN (National School of Biological Sciences of the National Polytechnic Institute) in Mexico City and at the Escuela Nacional de Agricultura (National School of Agriculture) in Chapingo in the southcentral state of Mexico. A major impulse toward the consolidation and institutionalization of genetics in Mexico came with the creation in 1960 of the Programa de Genética y Radiobiología (Genetics and Radiobiology Program). This program fostered research in different areas of genetics, encouraged training of its personnel in leading institutions of the United States and Europe, and promoted the teaching of genetics at the college level. Established by Alfonso León de Garay (1920-2002) in Mexico City, this program conducted research in animal, plant, human, and behavioral genetics and in cytogenetics and molecular biology; it also promoted the establishment of several genetics laboratories in different parts of Mexico (BARAHONa et al. 2003).

Theodosius Dobzhansky traveled to Mexico and col-

\footnotetext{
${ }^{1}$ Corresponding author: Departamento de Biología Evolutiva, Facultad de Ciencias, UNAM, Coyoacán 04510, México.

E-mail: abe@hp.fciencias.unam.mx

lected Drosophila flies there in 1935, 1936, and 1938. His lasting influence on Mexican genetics started several decades later, mostly mediated by de Garay, who invited Dobzhansky to lecture and facilitated the initiation of a major research project on the evolutionary genetics of natural populations of Drosophila. This project involved Mexican scientists as well as Dobzhansky's former students and collaborators from the United States. In this way Dobzhansky significantly contributed to the emergence and institutionalization of genetics in Mexico.

Theodosius Dobzhansky (1900-1975): Theodosius Dobzhansky was one of the most influential evolutionists of the twentieth century; he also was one of the most prolific. His first publication appeared in 1918 when Dobzhansky was 18 years old (Dobzhansky 1918). The complete list of his publications comprises nearly 600 titles, including a dozen books. ${ }^{2}$ For earlier Perspectives about Dobzhansky, see Powell (1987), Orr (1996), and LEwONTIN (1997). The gamut of subject matter is enormous. It includes results of experimental research in various biological disciplines, works of synthesis and theory, and essays on humanism and philosophy. The incredibly numerous and diversified published works of Dobzhansky are nevertheless unified-biological evolution is the theme that binds them together.

Dobzhansky's most significant contribution to science doubtless was his role in formulating and popularizing the modern synthesis of evolutionary theory. His Genetics and the Origin of Species, first published in 1937, is considered one of the most important books of evolutionary theory in the twentieth century. Extensively revised editions of this book were published in 1941 and 1951. Genetics of the Evolutionary Process, published in 1970, was

\footnotetext{
2Ayala (1985, 1990) are short scientific biographies of Dobzhansky. Ayala (1985) includes an extensive, nearly complete bibliography of Dobzhansky's publications.
} 


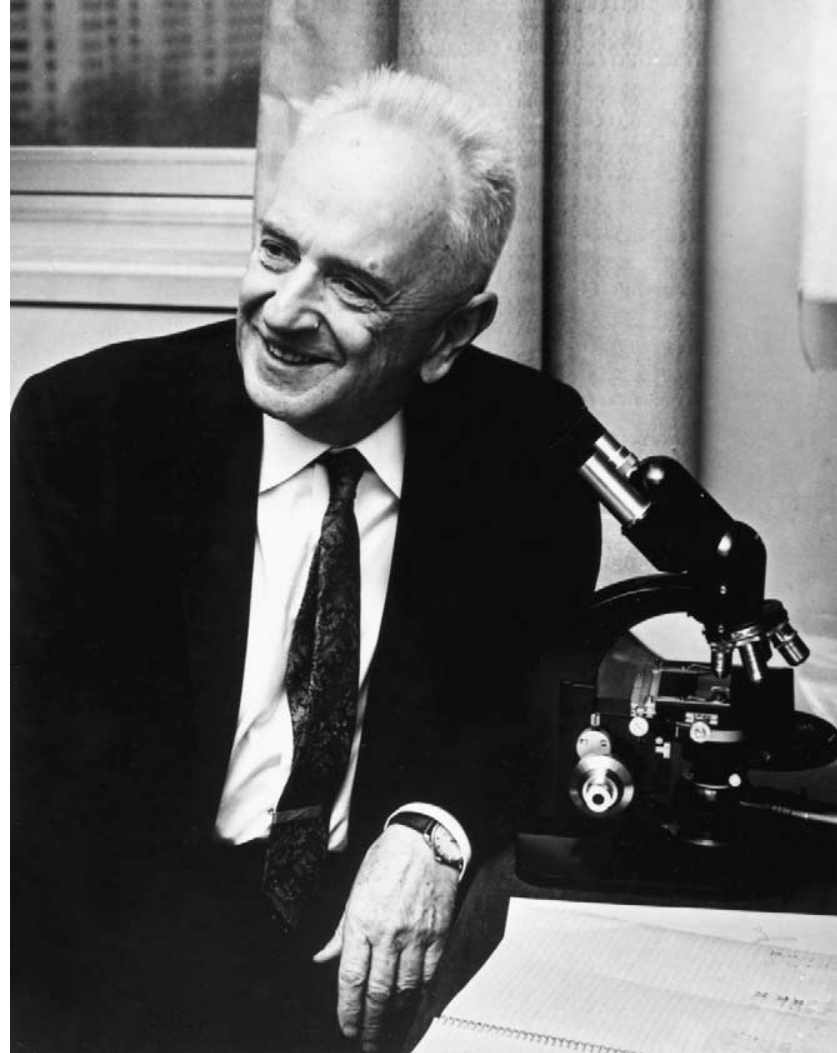

Th. Dobzhansky.

considered by Dobzhansky as the fourth edition of the earlier book, but it had changed too much to appear under the same title.

Dobzhansky extended the synthesis of Mendelism and Darwinism to the understanding of human nature in Mankind Evolving (1962), a successful synthesis of genetics, evolutionary theory, anthropology, and sociology. Dobzhansky expounded the idea that human nature has two dimensions: the biological, which humankind shares with the rest of life, and the cultural, which is exclusively human. Dobzhansky set forth that the individual is not the embodiment of some ideal type or norm, but rather a unique and unrepeatable realization in the field of quasi-infinite possible genetic combinations. The pervasiveness of genetic variation provides the biological foundation of human individuality and leads to demystification of the much-abused concept of race.

Theodosius Dobzhansky was born on January 25, 1900, in Nemirov, a small town $200 \mathrm{~km}$ southeast of Kiev in the Ukraine. He was the only child of Sophia Voinarsky and Grigory Dobrzhansky (a precise transliteration of the Russian family name includes the letter "r"), a teacher of high school mathematics. In 1910 the family moved to the outskirts of Kiev, where Dobzhansky lived through the tumultuous years of World War I and the Bolshevik revolution. In those times the family was often beset by various privations, including hunger.
Through his early high school years, Dobzhansky became an avid butterfly collector and studied ladybird beetles, which would be the subject of his first scientific publication (Dobzhansky 1918). He graduated in biology from the University of Kiev in 1921. He taught at the Polytechnic Institute in Kiev until 1924, when he became an assistant to Yuri Filipchenko, head of the new Department of Genetics at the University of Leningrad. Filipchenko was familiar with Thomas Hunt Morgan's work in the United States and had started a Drosophila laboratory, where Dobzhansky was encouraged to investigate the pleiotropic effects of genes.

In 1927, Dobzhansky obtained a fellowship from the International Education Board (Rockefeller Foundation) and arrived in New York on December 27 to work with Thomas Hunt Morgan at Columbia University. In the summer of 1928 he followed Morgan to the California Institute of Technology, where Dobzhansky was appointed assistant professor of genetics in 1929 and professor of genetics in 1936. In 1940 he returned to New York as professor of zoology at Columbia University, where he remained until 1961, when he became professor at the Rockefeller Institute (renamed Rockefeller University in 1965), also in New York City. On July 1, 1970, Dobzhansky became professor emeritus at Rockefeller University; in September 1971, he moved to the Department of Genetics at the University of California, Davis, California, where he was adjunct professor until his death in December 1975.

Throughout his academic career Dobzhansky had $>30$ graduate students and an even greater number of postdoctoral and visiting associates, many of them from foreign countries. Several distinguished geneticists and evolutionists in the United States and abroad are his former students and associates. Dobzhansky spent long periods of time in foreign academic institutions and was largely responsible for the establishment or development of genetics and evolutionary biology in various countries, notably Brazil, Chile, and Egypt. Dobzhansky's famous series of papers, under the general title "Genetics of natural populations," have been reprinted, along with insightful comments by LewONTIN et al. (1981).

Dobzhansky's unique contribution to genetics in Mexico, by his personality, his example, and his leadership is the subject of this essay.

Dobzhansky in Mexico (1935-1938): Dobzhansky first visited Mexico in 1935, as part of a Drosophila-collecting trip through Colorado, Arizona, New Mexico, Mexico, and Guatemala, subsidized by the Rockefeller Foundation. In Mexico, Dobzhansky met the Russian Dimitri Fyodorovich Sokoloff (1891-1973), who had obtained a Ph.D. in protozoology in St. Petersburg in 1917. During the Russian civil war Sokoloff's family moved to Japan, responding to an invitation from Junichi Ono, who had graduated with Sokoloff in Russia. In Japan, Sokoloff was able to carry out genetics research and 
teaching and be well paid, but his goal was "to emigrate to the United States when the opportunity arose" (Cox 2002). Sokoloff's children, Alexander ${ }^{3}$ and Nina, were born in Japan in 1920 and 1923, respectively. After 1923, Sokoloff sought to move to the United States, but immigration quotas for Russians were filled. Instead, with aid from the Red Cross, Sokoloff's family emigrated to Mexico, where he accepted a teaching position at the Escuela Normal Superior (Normal School for Teachers) in Toluca, $66 \mathrm{~km}$ southwest of Mexico City. Later he moved to the National University of Mexico in Mexico City, and eventually to the Escuela Nacional de Ciencias Biológicas (ENCB; National School of Biological Sciences) of the National Polytechnic Institute, also in Mexico City, where he remained for many years (А. SокоLOFF, personal communication).

Dobzhansky had heard of Sokoloff and contacted him during his 1935 visit. Sokoloff invited him to dinner and introduced him to his 15-year-old son, Alexander, who persuaded Dobzhansky to take him along as an assistant on the Drosophila-collecting expedition and who would later become a long-term friend (Cox 2002; A. Sokoloff, personal communication).

One goal of Dobzhansky's expedition was to collect Drosophila species, particularly Drosophila pseudoobscura and D. azteca, to study their geographic distribution and also to settle some issues concerning the taxonomy and evolution of $D$. azteca populations by studying their giant salivary gland chromosomes. The polytene chromosomes of D. azteca are thin and frequently appear scrambled and interwoven in the salivary glands, making identification difficult, even when their size and bandstaining pattern are similar to those of other species. Dobzhansky proceeded by crossing individual sons of wild gravid females to females from a Cuernavaca strain, which had been arbitrarily chosen as standard. Different sequence patterns of the $\mathrm{X}$ chromosome, called $\alpha, \beta$, and $\gamma$, were used for constructing maps and phylogenetic trees showing the derivation of patterns from one another. ${ }^{4}$

The significance of chromosomal inversions for investigating genetic and evolutionary questions can be traced to Sturtevant's (1913) publication of the first chromosome map, which included six genes present on the X chromosome of D. melanogaster (Crow 1988). Sturtevant hypothesized that the recombination fre-

\footnotetext{
${ }^{3}$ Alexander Sokoloff got his Ph.D. at the University of Chicago in 1954 under the direction of Thomas Park and Dobzhansky, who was at the time on the faculty of Columbia University in New York, with a thesis entitled "Competition between sibling species of the pseudoobscura subgroup of Drosophila." He became a professor at California State University, San Bernardino, California, in 1966.

${ }^{4}$ See Dobzhansky and Socolov (1939). A Spanish version of this article had been published a year earlier: Dobzhansky and SokolofF (1938). Note the variant spellings of Sokoloff's name in the two publications.
}

quency between linked genes was directly related to their linear distance along the chromosomes, a proposal that initiated the fertile field of gene mapping. It would later be established that there is a linear correspondence between the sequence of genes in the genetic maps and the dark and light bands in the polytene chromosomes of the salivary glands. In 1926, Sturtevant (1926) showed that the so-called $\mathrm{C}$ factors, which had the property of suppressing crossing over, were associated with inversions in the gene sequence, which was later confirmed in giant salivary gland chromosomes. STURTEvant and Dobzhansky (1936) later discovered that chromosome inversions were often present as polymorphisms in several natural populations of different species of Drosophila.

Chromosome inversions frequently overlap along a chromosome, an observation exploited by DobzHansky and EPLING (1944) to infer the succession in which the inversions have arisen one from another, although not their temporal direction; i.e., whether a chromosome band arrangement was ancestral or descendant could not be determined (the method was first introduced and applied by Sturtevant and Dobzhansky 1936). Although the direction of a particular change could not be determined, this was often apparent from the entire set. Dobzhansky would for many years exploit this discovery for reconstructing phylogenetic "trees" reflecting ancestor-descendant relationships between chromosome arrangements within and between species. This genetic method for reconstructing evolutionary biology would later be extended by Fitch and Margoliash (1967) for determining the phylogeny of protein sequences from different species and, thereby, the phylogeny of the species. Protein and DNA sequences would eventually be used to reconstruct the evolutionary history of populations from the same species, a new subdiscipline called phylogeography. This has become a burgeoning field of evolutionary research (Avise 2000). The chromosome trees constructed by Dobzhansky and collaborators over many years may be seen as early examples of species phylogenies as well as of phylogeography, since chromosome polymorphisms were often associated with distinct geographic localities.

Dobzhansky returned to Mexico for collecting $D$. pseudoobscura and related species in 1936 and $1938 .{ }^{5}$ Collections were made in 18 localities in September of 1936 and in February and March of 1938. Dobzhansky reported extensive polymorphisms regarding genetic rearrangements in chromosome III of D. pseudoobscura (while the remaining chromosomes were largely invari-

\footnotetext{
${ }^{5}$ Provine (1981, p. 33) and Levine et al. (1995, p. 121) report only two collecting trips of Dobzhansky in Mexico, in 1935 and 1938, but he was also there in 1936. Collections made in September 1936 are reported in Dobzhansky (1939), where he thanks Dimitri Sokoloff and Leandro Luján for collaborating in the collections.
} 
able), the presence of some variation in the Y chromosome configuration, incidence of recessive lethal and semilethal genes, and some deleterious developmental modifiers (Dobzhansky 1939). Dobzhansky reported 13 inversion rearrangements of chromosome III, 9 of them in Mexico and the others in Guatemala.

Upon Dobzhansky's return to the United States, Dimitri Sokoloff accepted an invitation to visit him at Caltech during 1938 to investigate the salivary gland chromosomes of D. azteca. Before Sokoloff left CalTech, Dobzhansky gave him six handwritten experiments to help him in his genetics courses at ENCB (A. Sokoloff, personal communication). After returning to Mexico, D. Sokoloff accepted an administrative job as head of the parasitology department, but voluntarily retired from the ENCB in 1945, so that he could move with his family to Chicago. There he accepted a teaching position at Mundelein College, where he remained until the end of his academic life. Dobzhansky's friendship with the Sokoloffs persisted through Alexander, son of Dimitri, until Dobzhansky's own death in December 1975.

Dobzhansky did not return to Mexico in the immediately ensuing years after 1938, because the Second World War made it difficult to travel abroad (T. DobZHANSKY to F. J. Ayala, personal communication). After 1941, when the United States entered the war, Dobzhansky no longer had American Ph.D. students. He continued to teach at Columbia University while his Soviet immigrant status kept him from participating in the war effort. It was during the later years of the war that some Latin American graduate students and young scientists came to work with him at Columbia and he himself visited Brazil on at least two occasions, in 1944 and 1945. ${ }^{6}$

Dobzhansky in Mexico (1974-1975): The Genetics and Radiobiology Program, founded by de Garay in 1960, was part of the National Commission of Nuclear Energy, which had been established in 1956. The Genetics and Radiobiology Program was fundamental to the development of genetics in Mexico through the training of scientists, the initiation of genetics research programs, and the teaching of the discipline in colleges and universities. ${ }^{7}$ One of the young scientists sent for training abroad was Victor Salceda. In 1965 he spent 2 years at Dobzhansky's laboratory at Rockefeller University in New York. There, he specialized in population genetics. Salceda was supported by a fellowship from the International Atomic Energy Organization. In his first year, he worked on the genetic load of chronically

\footnotetext{
${ }^{6}$ For the influence of Dobzhansky in Latin American countries, see Brncic (1995), Cordeiro and Winge (1995), and Krimbas (1995).

${ }^{7}$ More about the Genetics and Radiobiology Program and about de Garay's life and contributions to genetics can be found in BARAHONA et al. (2003).
}

irradiated populations of D. melanogaster. In his second year, he collaborated with two visiting members of Dobzhansky's laboratory, David Crumpacker and Dragoslav Marinkovic, who were investigating chromosome inversion polymorphisms in D. pseudoobscura. Upon his return to Mexico, and following Dobzhansky's suggestion, Salceda proposed to de Garay that he continue with Dobzhansky's collections of D. pseudoobscura in Mexico, seeking more fully to describe and understand the patterns of geographic distribution of the third chromosome inversion polymorphisms. Salceda's training at Rockefeller University had prepared him to recognize these inversions, and thus he was well prepared to lead the Mexican scientists who would participate in the project. The intention was that the project would be initiated in 1968, when Dobzhansky would come to Mexico to lecture and participate in the collections. In the meantime, Salceda concentrated on finishing his doctorate studies. After graduating, Salceda was hired by the Colegio de Posgraduados at Chapingo (Chapingo Postgraduate School).

de Garay met one of us, F. J. Ayala, in 1966 in Chicago during the Third International Congress of Human Genetics (September 6-10, 1966). A correspondence was initiated between de Garay and Ayala, no later than September 12, 1966, which would persist at frequent intervals until 1976. de Garay invited Ayala to lecture in Mexico, an invitation that Ayala was "finally able to accept" for June 1968. de Garay had also invited Dobzhansky at various times to lecture in Mexico, an invitation that Dobzhansky accepted for June and July 1968, when he intended to travel with Ayala to Mexico, not only for lecturing but also for collecting $D$. pseudoobscura in several Mexican localities, joined there by Salceda and other Mexican scientists. Ayala's lecture, sponsored by the Mexican Genetics Society, took place in June 1968 (he would lecture in Mexico again in 1974 and 1976 at the invitation of de Garay), but Dobzhansky canceled his trip and thus the $D$. pseudoobscura project did not get started at this time. The reason for Dobzhansky's cancellation (although this reason was not given to de Garay at the time) was that on June 1, 1968, during a routine checkup, Dobzhansky was diagnosed as suffering from a relatively mild form of leukemia. Consequently, he canceled most or all of his planned travels for the immediate future, so that he could concentrate on writing the intended fourth edition of Genetics and the Origin of Species, which eventually was published under a different title, Genetics of the Evolutionary Process, $1970 .^{8}$

During the XIII International Genetics Congress in

\footnotetext{
${ }^{8}$ Correspondence files (1966-1976) of Francisco J. Ayala, Department of Ecology and Evolutionary Biology, University of California, Irvine, California.
} 


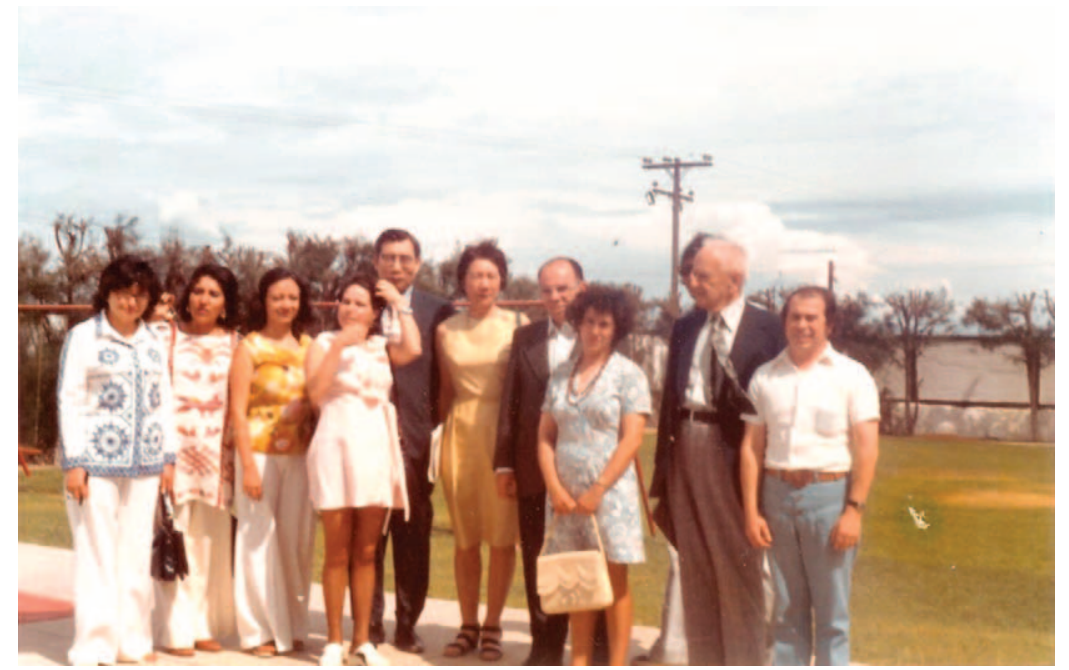

The Dobzhansky Drosophila collecting group in Mexico ca. 1974. Dobzhansky is second from the right; population geneticist C. C. Li is fifth from the left.

Berkeley, California, in 1973, de Garay met Dobzhansky in person. According to Levine et al. (1995, p. 120),

On one of the days of the congress, Theodosius Dobzhansky (Dodik), Jeffrey R. Powell, and Wyatt W. Anderson approached me (Levine) and asked that I arrange a meeting with Dr. Alfonso L. de Garay ... I had been associated with the genetics group at the institute [the Genetics and Radiobiology Program] since 1965 and had participated in a number of their projects. Dodik, Jeff, and Wyatt were interested in studying the Mexican populations of D. pseudoobscura and needed both a base of operations and the collaboration of a group of local geneticists. I was delighted to arrange the requested meeting, and Dr. de Garay recognized immediately the worthiness of the project and agreed to have his laboratory participate in it.

Indeed, de Garay had been interested in the project since 1968, when he had invited Dobzhansky to come to Mexico to lecture and to get the project started.

The "Population Genetics of Mexican Drosophila" project was initiated in 1974 with the financial support of the U.S. National Science Foundation and the Mexican Consejo Nacional de Ciencia y Tecnología (CONACyT; National Council for Science and Technology). ${ }^{9}$ In getting the project started, de Garay once again invited Dobzhansky to Mexico, this time to be principal speaker in the First Mexican Genetics Congress celebrated in the city of Mazatlán, in the north-west state of Sinaloa, in July of 1974. Dobzhansky delivered a keynote address that was separately printed and distributed in Mexico. ${ }^{10}$ As earlier, the research project was planned to investigate the third chromosome inversion polymorphisms

\footnotetext{
${ }^{9}$ National Science Foundation grant OIP 75-06738 and contract number 651 from CONACyT.

${ }^{10}$ On March 11, 1976, shortly after Dobzhansky's death in December 1975, de Garay wrote to Ayala: "I have reprints of the Professor's [Dobzhansky] lecture and will send you 50 if you want them." Correspondence files (1966-1976) of Francisco J. Ayala, Department of Ecology and Evolutionary Biology, University of California, Irvine, California.
}

in D. pseudoobscura. Collections would be made first in two populations located in the central region of Mexico and later elsewhere throughout the country. The main participants in the project were the Americans Louis Levine and Jeffrey Powell, both former students of Dobzhansky, and the Mexicans Rodolfo Félix, Olga Olvera, Judith Guzmán, Victor Salceda, and María Esther de la Rosa.

Two research objectives had been identified. First, to understand the ecological basis of genetic variation in natural populations of $D$. pseudoobscura by determining the relationship between the ecological diversity of the environment (particularly with respect to food sources) and the degree of genetic polymorphism. Second, to determine the relationship between the amount of genetic variation present in a population and its rate of evolution.

Collecting trips took place in the summer of 1974 (while Dobzhansky was in Mexico), December 1974, and the spring of 1975. These collections were made in three main locations, all in central Mexico: Parque Nacional El Chico (El Chico National Park) close to Pachuca, Hidalgo; Amecameca, in the state of Mexico; and Zirahuen, near lake Pátzcuaro, Michoacán. Two new chromosome inversions were described in the first publication emerging from the project (Dobzhansky et al. 1975). Moreover, in a collection from Cuernavaca, $70 \mathrm{~km}$ south of Mexico City, a new species was discovered, Drosophila cuauhtemoci, closely related to D. pseudoobscura (FÉLIX et al. 1976). By 1975, in addition to chromosome inversions, allozyme polymorphisms had become an important tool for investigating genetic variation in natural populations. In the first publication on the project, Dobzhansky et al. (1975, p. 205) point out an important advantage of chromosome over allozyme polymorphisms for investigating phylogeography (without using this term, coined years later): "While similar gene alleles may arise repeatedly and in different populations by independent mutations, chromosomal inver- 
sions are almost certainly monophyletic. A gene arrangement found in millions or billions of individuals over many thousands of square miles must have started as a chromosome carried in a single fly. This makes the geographic distribution of the inversions historically more informative than that of mutant genes."

After Dobzhansky's death in December 1975, Wyatt W. Anderson took his place in the project. Some 20 articles derived from the project were published in various journals between 1975 and 1995, and several papers were presented at Mexican and international meetings. The results elucidated include that females in the wild not only can, but also often do, have multiple matings; that wild adult males and the zygotes of the second generation often differ in the frequency of chromosome rearrangements, reflecting sexual selection; and that polymorphisms are subject to selection in response to the environment, changing in direction and intensity according to environmental pressures and modifications in the genetic constitution of each population. ${ }^{11}$

About 40 third chromosome inversion rearrangements are known in D. pseudoobscura, 26 of which have been found in Mexican populations. According to Vavilov (MANGelsdorf 1953; Crow 1993), populations localized in the distribution center of a species are expected to possess more genetic variability than populations in the periphery (Olvera et al. 1979). Therefore, the large incidence of chromosome polymorphisms in Mexico, particularly in the central region where the state of Michoacán is located, raises the question whether the central area of Mexico has been the dispersion center of the species or whether the huge polymorphism is simply a peculiarity of the species in this area. One hypothesis proposes that $D$. pseudoobscura emerged in central Mexico, whence it dispersed through the moist forests to the north all the way to British Columbia, as well as to the south to Guatemala and Nicaragua. A propagule reached the altiplano near Bogotá, Colombia, where there is a geographically isolated population of the species. Thanks to the project initiated by Dobzhansky, a phylogenetic tree that includes all 40 chromosome rearrangements of $D$. pseudoobscura now exists, including the so-called "hypothetical," which still remains to be found (Olvera et al. 1985).

Mexican geneticists were fortunate that Dobzhansky extended his activities to Mexico, even though this was toward the end of his life. Dobzhansky's influence on Mexican geneticists and Mexican genetics, particularly population and evolutionary genetics, persists to the present. Population genetics is now thriving in Mexico due in no small part to the influence of Dobzhansky's

\footnotetext{
${ }^{11}$ One of the final publications of the project (Levine et al. 1995) concludes: "This paper is dedicated to Dr. Alfonso L. de Garay and to the memory of Th. Dobzhansky, initiators and guiding spirits of this program."
}

ideas, the force of his strong personality, and the stimulus that he provided for some of his American students and collaborators to become involved in research projects with Mexican collaborators. Twenty years after the Drosophila research project began and, after reviewing the work accomplished, Levine et al. (1995, p. 138) recalled: "We have reviewed our work on the Mexican populations of $D$. pseudoobscura and have indicated how central Theodosius Dobzhansky was and remains in our investigations. The evolutionary process that he studied so intensively reveals its complexity with each new piece of research and continues to attract and excite geneticists. If we have provided information that sparks further discussion or have indicated some areas of research that hold promise for a better understanding of the process, we will have done what we believe Dobzhansky would have wanted us to do."

We thank the late Alfonso León de Garay for interviews, archive files, and other contributions to this research project. Judith Guzmán and Olga Olvera provided valuable information, for which we are grateful.

\section{LITERATURE CITED}

Avise, J. C., 2000 Phylogeography: The History and Formation of Species. Harvard University Press, Cambridge, MA.

Ayala, F. J., 1985 Theodosius Dobzhansky 1900-1975. Biogr. Mem. Natl. Acad. Sci. 55: 163-213.

Ayala, F. J., 1990 Dobzhansky, Theodosius, pp. 233-242 in Dictionary of Scientific Biography, Vol. 17, Suppl. II. Charles Scribner's Sons, New York.

Barahona, A., S. Pinar and F. J. Ayala, 2003 La Genética en México: Institucionalización de una Disciplina. Universidad Nacional Autónoma de México, Mexico.

Brncic, T., 1995 Colonization of Chile by Drosophila subobscura and its consequences, pp. 154-169 in Genetics of Natural Populations: The Continuing Importance of Theodosius Dobzhansky, edited by L. Levine. Columbia University Press, New York.

Cordeiro, A. R., and H. Winge, 1995 Levels of evolutionary divergence of Drosophila willistoni sibling species, pp. 262-279 in Genetics of Natural Populations: The Continuing Importance of Theodosius Dobzhansky, edited by L. Levine. Columbia University Press, New York.

Cox, R. S., 2002 The periodicity of swallows: Sokoloff, Montagu, Sutton, Whitney, and Sepkoski. Mendel Newsl. 11: 18-22.

Crow, J. F., 1988 A diamond anniversary: the first chromosome map. Genetics 118: 1-3.

Crow, J. F., 1993 N. I. Vavilov, martyr to genetic truth. Genetics 134: $1-4$.

Dobzhansky, T., 1918 Description of a new species of the genus Coccinella from the neighbourhood of Kiev. Fauny Iugozap. Rossii 2: 46-47 (in Russian).

Dobzhansky, Th., 1939 Genetics of natural populations. IV. Mexican and Guatemalan populations of Drosophila pseudoobscura. Genetics 24: 391-412.

Dobzhansky, Th., and C. Epling, 1944 Contributions to the genetics, taxonomy and ecology of Drosophila pseudoobscura and its relatives. Carnegie Inst. Washington Publ. 554: 1-183.

Dobzhansky, Th., and D. Socolov, 1939 Structure and variation of the chromosomes in Drosophila azteca. J. Hered. 30: 3-19.

Dobzhansky, Th., and D. Sokoloff, 1938 Estructura y variación de los cromosomas en Drosophila azteca Sturtevant \& Dobzhansky. Anales de la Escuela Nacional de Ciencia Biológicas 22: 37-62.

Dobzhansky, Th., R. Félix, J. Guzmán, L. Levine, O. Olvera et al., 1975 Population genetics of Mexican Drosophila I: chromosomal variation in natural populations of Drosophila pseudoobscura from Central México. J. Hered. 66: 203-206. 
Félix, R., J. Guzmán, L. Levine, O. Olvera, J. R. Powell et al., 1976 Population genetics of Mexican Drosophila II. A new species of the obscura group of the genus Drosophila (Diptera, Drosophilidae). Pan-Pac. Entomol. 52: 167-171.

Fitch, W. M., and E. Margoliash, 1967 Construction of phylogenetic trees. Science 155: 279-284.

Kass, L. B., C. Bonneuil and E. H. Coe, JR., 2005 Cornfests, cornfabs and cooperation: the origins and beginnings of the Maize Genetics Cooperation News Letter. Genetics 169: 1787-1797.

Krimbas, C. B., 1995 Resistance and acceptance: tracing Dobzhansky's influence, pp. 23-36 in Genetics of Natural Populations: The Continuing Importance of Theodosius Dobzhansky, edited by L. LEvINE. Columbia University Press, New York.

Levine, L., O. Olvera, J. R. Powell, R. F. Rockwell, M. E. Rosa et al., 1995 Studies on Mexican populations of Drosophila pseudoobscura, pp. 120-139 in Genetics of Natural Populations: The Continuing Importance of Theodosius Dobzhansky, edited by L. Levine. Columbia University Press, New York.

Lewontin, R. C., 1997 Dobzansky's genetics and the origin of species: Is it still relevant? Genetics 147: 351-355.

Lewontin, R. C., J. A. Moore, W. B. Provine and B. Wallace (Editors), 1981 Dobzhansky's Genetics of Natural Populations I-XLIII. Columbia University Press, New York.

Mangelsdorf, P. C., 1953 Nikolai Ivanovitch Vavilov, 1887-1942. Genetics 38: 1-4.

Nelson, O. E., 1993 A notable triumvirate of maize geneticists. Genetics 135: 937-941.
Olvera, O., R. F. Rockwell, M. E. Rosa, V. M. Salceda, M. I. GAso et al., 1979 Population genetics of Mexican Drosophila. VI. Cytogenetic aspects of the inversion polymorphism in D. pseudoobscura. Evolution 33: 381-395.

Olvera, O., R. F. Rockwell, M. E. Rosa, M. I. Gaso, F. Gonzalez et al., 1985 Chromosomal and behavioral studies of Mexican Drosophila III. Inversion polymorphism of D. pseudoobscura. J. Hered. 76: 258-262.

OrR, H. A., 1996 Dobzhansky, Bateson, and the genetics of speciation. Genetics 144: 1331-1335.

Powell, J. R., 1987 "In the air"-Theodosius Dobzhansky's "Genetics and the Origin of Species." Genetics 117: 363-366.

Provine, W. B., 1981 Origins of the genetics of natural populations series, pp. 5-83 in Dobzhansky's Genetics of Natural Populations IXLIII, edited by R. C. Lewontin, J. A. Moore, W. B. Provine and B. Wallace. Columbia University Press, New York.

Sturtevant, A. H., 1913 The linear arrangement of six sex-linked factors in Drosophila, as shown by their mode of association. J. Exp. Zool. 14: 43-59.

Sturtevant, A. H., 1926 A crossover reducer in Drosophila melanogaster due to inversion of a section of the third chromosome. Biol. Zent. Bl. 46: 697-702.

Sturtevant, A. H., and T. Dobzhansky, 1936 Inversions in the third chromosome of wild races of Drosophila pseudoobscura, and their use in the study of the history of the species. Proc. Natl. Acad. Sci. USA 22: 448-450. 
